\title{
PENGARUH PEMBELAJARAN KOOPERATIF TIPE THINK PAIR SHARE TERHADAP KEMAMPUAN BERPIKIR KRITIS DAN HASIL BELAJAR MATEMATIKA SISWA KELAS VI DI SD MUHAMMADIYAH 12 MEDAN
}

\author{
Ismail Saleh Nasution \\ Pendidikan Matematika, Universitas Muhammadiyah Sumatera Utara \\ ismail.salehnasution@yahoo.com
}

\begin{tabular}{l} 
INFO ARTIKEL \\
\hline RiwayatArtikel: \\
Diterima: 12-09-2017 \\
Disetujui: $30-09-2017$ \\
\end{tabular}

Kata Kunci:

Think Pair Share

Berpikir Kritis

Hasil Belajar

\begin{abstract}
ABSTRAK
Abstrak : Penelitian ini bertujuan untuk mengetahui: (1) mengetahui perbedaan pengaruh strategi pembelajaran kooperatif terhadap pasangan berpikir, strategi pembelajaran kooperatif jigsaw, dan pembelajaran konvensional terhadap kemampuan berpikir kritis siswa dalam mata pelajaran menghitung luas dan volume di kelas enam Muhammadiyah 12 Medan; dan (2) untuk mengetahui perbedaan pengaruh strategi pembelajaran kooperatif terhadap pasangan berpikir, strategi pembelajaran kooperatif jigsaw, dan pembelajaran konvensional terhadap hasil belajar siswa dalam mata pelajaran menghitung luas dan volume di kelas enam Muhammadiyah 12 Medan. Subjek dalam penelitian ini diambil sebanyak tiga kelas dengan teknik random random sampling. Metode penelitian menggunakan desain penelitian kuasi eksperimental dengan rancangan kelompok percobaan pretest group posttestt. Berdasarkan hasil yang diperoleh: (1) Keterampilan berpikir kritis siswa yang belajar dengan strategi pembelajaran kooperatif menganggap pasangan berpasangan secara signifikan lebih tinggi daripada kemampuan berpikir kritis siswa yang belajar dengan strategi pembelajaran kooperatif jigsaw dan yang dipelajari dengan strategi Konvensional; dan (2) Hasil pembelajaran siswa yang dipelajari oleh strategi pembelajaran kooperatif, think pair share secara signifikan lebih tinggi daripada yang dipelajari dengan hasil pembelajaran strategi pembelajaran kooperatif jigsaw dan yang dipelajari dengan strategi konvensional. Hasil yang diperoleh diharapkan dapat memberikan informasi bagi guru dan sekolah untuk menggunakan strategi pembelajaran kooperatif berfikir pasangan berbagi untuk meningkatkan kemampuan berpikir kritis dan materi pelajaran Hasil pembelajaran matematika menghitung luas dan volume di kelas enam.
\end{abstract}

\begin{abstract}
This study aims to determine: (1) to determine differences in the effect of cooperative learning strategy think pair share, jigsaw cooperative learning strategies, and conventional learning to students' critical thinking skills in the subject matter calculate area and volume in sixth grade Muhammadiyah 12 Medan; and (2) to determine differences in the effect of cooperative learning strategy think pair share, jigsaw cooperative learning strategies, and conventional learning on learning outcomes of students in the subject matter calculate area and volume in sixth grade Muhammadiyah 12 Medan. Subjects in this study were taken as many as three classes randomly selected random sampling techniques. The research method using quasiexperimental research design with pretest group-posttestt experiment group design. Based on the results obtained: (1) The critical thinking skills of students that learned by cooperative learning strategy think pair share was significantly higher than the students' critical thinking skills that learned with a jigsaw cooperative learning strategies and that learned with strategy Conventional; and (2) The results of student learning that learned by cooperative learning strategy think pair share was significantly higher than that learned with the learning outcomes of cooperative learning strategies jigsaw and that learned with conventional strategies. The results obtained are expected to provide information for teachers and schools to use cooperative learning strategies think pair share to improve critical thinking skills and subject matter Mathematics learning outcomes calculate area and volume in sixth grade.
\end{abstract}




\section{A. LATAR BELAKANG}

Pendidikan merupakan salah satu aspek dalam kehidupan yang memegang peranan penting sehingga suatu negara dapat mencapai sebuah kemajuan dalam teknologinya, jika pendidikan dalam negara itu baik kualitasnya. Tinggi rendahnya kualitas pendidikan dalam suatu negara dipengaruhi oleh banyak faktor, baik siswanya, pengajar (guru), sarana prasarana, dan faktor lingkungan sekolah. Dalam hal ini sekolah menjadi tempat guru dan siswa berinteraksi dan berkomunikasi untuk kebutuhan ilmu pengetahuan. Guru bertindak sebagai pengajar sekaligus sumber ilmu pengetahuan bagi siswa, sedangkan siswa berperan sebagai orang yang ditargetnya memiliki pengetahuan nantinya.

Proses pembelajaran yang berlangsung antara guru dan siswa pada dasarnya merupakan transformasi pengetahuan, sikap, dan keterampilan dengan melibatkan aktivitas fisik dan mental. Keterlibatan siswa baik secara fisik maupun mental merupakan bentuk pengalaman belajar siswa yang dapat memperkuat pemahaman siswa terhadap konsep pembelajaran. Guru sebagai tenaga pendidik profesional diharapkan mampu memilih dan menggunakan strategi pembelajaran yang sesuai dengan materi pelajaran sehingga dapat mengembangkan kemampuan berpikir kritis siswa. Guru mempunyai peran yang penting dalam proses pembelajaran, karena pada saat mengajar bukan hanya sekedar menyampaikan materi pelajaran, akan tetapi proses mengubah perilaku siswa sesuai dengan tujuan yang diharapkan. Selama proses pembelajaran guru harus menjadi contoh bagi siswa, membimbing siswa, melatih keterampilan intelektual maupun keterampilan motorik siswa, serta membentuk siswa yang memiliki kemampuan inovatif dan kreatif. Menurut Syah (2008), menyatakan proses belajar mengajar adalah sebuah kegiatan yang integral (utuh terpadu) antara siswa sebagai pelajar yang sedang belajar dengan guru sebagai pengajar.

Untuk menjamin proses pendidikan tidak lari dari jalur yang ditetapkan Negara, pemerintah mengeluarkan kurikulum sebagai acuan pembelajaran. Undang-Undang Republik Indonesia nomor 20 tahun 2003 pasal 1 bab 1 disebutkan bahwa "Kurikulum adalah seperangkat rencana dan pengaturan mengenai tujuan, isi, dan bahan pelajaran serta cara yang digunakan sebagai pedoman penyelenggaraan kegiatan pembelajaran untuk mencapai tujuan pendidikan tertentu." Sejalan dengan kehadiran kurikulum 2013 tidak lepas dari kurikulum sebelumnya, yakni KTSP tahun 2006. Kurikulum 2013 sebagai hasil dari penjabaran Permendikbud No. 65 Tahun 2013 tentang Standar Proses Pendidikan Dasar dan Menengah yang mengisyaratkan tentang perlunya proses pembelajaran yang dipandu dengan kaidah-kaidah pendekatan saintifik atau ilmiah. Sebagaimana disebutkan Sudrajat (2013) bahwa kehadiran kurikulum 2013 menjadikan menjadikan siswa lebih aktif dalam mengkonstruksi pengetahuan dan keterampilannya, juga dapat mendorong siswa untuk melakukan penyelidikan guna menemukan fakta-fakta dari suatu fenomena atau kejadian. Artinya, dalam proses pembelajaran, siswa dibelajarkan dan dibiasakan untuk menemukan kebenaran ilmiah, bukan diajak untuk beropini dalam melihat suatu fenomena. Dengan demikian, kurikulum 2013 lebih menargetkan pada capaian keberhasilan siswa dalam setiap proses belajarnya. Salah satu mata pelajaran yang mendapat perhatian serius adalah Matematika.

Kemendikbud (2013:iii) mengemukakan matematika adalah bahasa universal untuk menyajikan gagasan atau pengetahuan secara formal dan presisi sehingga tidak memungkinkan terjadinya multi tafsir. Penyampaiannya adalah dengan membawa gagasan dan pengetahuan konkret ke bentuk abstrak melalui pendefinisian variabel dan parameter sesuai dengan yang ingin disajikan. Penyajian dalam bentuk abstrak melalui matematika akan mempermudah analisis dan evaluasi selanjutnya. Coockrofi (dalam Abdurahman, 1999:253) mengemukakan alasan tentang perlunya belajar matematika yaitu: Matematika perlu diajarkan kepada siswa karena: (1) selalu digunakan dalam segala kehidupan; (2) semua bidang studi memerlukan keterampilan matematika yang sesuai; (3) memfasilitasi sarana komunikasi yang kuat, singkat dan jelas; (4) dapat digunakan untuk menyajikan informasi dalam berbagai cara; (5) meningkatkan kemampuan berpikir logis, ketelitian, dan kesadaran ruangan; dan (6) memberikan kepuasan terhadap usaha memecahkan masalah.

Alasan pentingnya matematika untuk dipelajari karena begitu banyak kegunaannya antara lain: dengan belajar matematika kita mampu berhitung dan mampu melakukan perhitungan-perhitungan lainnya, matematika merupakan persyaratan untuk beberapa mata pelajaran lainnya, dengan belajar matematika perhitungan menjadi lebih sederhana dan praktis, dengan belajar matematika diharapkan siswa mampu menjadi manusia yang berpikir logis, kritis, tekun, bertanggung jawab dan mampu menyelesaikan persoalan (Ruseffendi, 1991:70). Dari pendapat di atas dapat disimpulkan bahwa pembelajaran matematika di sekolah dapat memberikan siswa kemampuan menalar dan memahami hal-hal yang terjadi di sekitarnya. Hal ini mengindikasi bahwa pembelajaran matematika penting diberikan di sekolah dengan tujuan memberikan kemampuan berpikir logis kepada siswa untuk memahami berbagai situasi (kondisi) yang ada di sekitarnya.

Keberhasilan siswa dalam pembelajaran Matematika terlihat dari perubahan sikap dan tingkah laku atau dari hasil belajar yang dicapai siswa di sekolah. Tercapai tidaknya hasil belajar siswa ditentukan dari kemampuan siswa mencapai nilai ketentuan ketuntasan minimum (KKM) yang ditetapkan pemerintah. Untuk mata pelajaran Matematika nilai KKM ditetapkan 7,0. Kenyataan yang diperoleh peneliti di lapangan, tidak semua siswa mendapatkan hasil yang optimal sesuai yang diinginkan guru. Hal ini terlihat dari hasil belajar Matematika siswa kelas VI SD Muhammadiyah 12 Medan. Rendahnya hasil belajar siswa juga dibuktikan dari perolehan nilai ulangan tengah semester siswa kelas VI SD Muhammadiyah 12 Medan. Nilai rata-rata ulangan Matematika siswa yang dilaksanakan bulan Oktober 2014 sebesar 67,4 dengan jumlah siswa yang mencapai KKM Matematika sekitar $72 \%$ dari 78 siswa. Hasil Matematika ini mengharuskan guru Matematika melakukan ujian remedial (perbaikan) bagi siswa yang belum mencapai KKM. Hasil formatif Matematika di atas mencerminkan daya serap mereka terhadap materi pelajaran yang diterimanya. 
Berdasarkan pengamatan Pengawas SD Kota Medan pada guru kelas VI SD Muhammadiyah 12 Medan diperoleh gambaran bagaimana cara guru mengajar Matematika di kelas. Guru kelas masih menggunakan metode konvensional, yaitu dengan cenderung menggunakan metode ceramah diselingi tanya jawab dan penugasan. Dengan metode ini siswa hanya memperoleh sejumlah informasi yang bersumber kepada guru saja. Informasi dan komunikasi yang terjadi satu arah ini menyebabkan siswa lebih banyak menunggu tanpa berbuat sesuatu untuk menemukan sendiri konsep-konsep matematika. Guru lebih banyak berbuat, sementara siswa hanya menunggu informasi yang telah mereka peroleh dari sumber lain di lingkungannya yang erat hubungannya dengan materi yang sedang mereka pelajari. Selain itu banyak siswa yang menganggap matematika sebagai pelajaran hafalan, siswa tidak dapat melihat hubungan antar materi pelajaran yang telah dipelajari dengan materi berikutnya. Mereka harus mengingat-ingat informasi atau penjelasan guru dan menceritakannya kembali pada waktu ulangan atau ujian. Sehingga hal tersebut berpengaruh terhadap hasil belajar matematika siswa (Rustaman, dkk., 2003).

Dalam pembelajaran matematika diperlukan suatu proses berpikir karena matematika pada hakikatnya berkenaan dengan stuktur dan ide abstrak yang disusun secara sistematis dan logis melalui proses penalaran deduktif. Oleh karena itu dalam mempelajari matematika kurang tepat bila dilakukan dengan cara menghafal namun, matematika dapat dipelajari dengan baik dengan cara mengerjakan latihan-latihan. Dalam proses mengerjakan latihan-latihan tersebutlah mulai berpikir bagaimana merumuskan masalah, merencanakan penyelesaian, mengkaji langkah-langkah penyelesaian, membuat dugaan bila data yang disajikan kurang lengkap diperlukan sebuah kegiatan berpikir yang disebut berpikir kritis.

Hal ini dikarenakan matematika merupakan ilmu yang mempunyai ciri-ciri khusus, salah satunya adalah penalaran dalam matematika yang bersifat deduktif aksiomatis yang berkenaan dengan ide-ide, konsep-konsep, dan simbol-simbol yang abstrak serta tersusun secara hierarkis, sehingga dalam pendidikan dan pengajaran matematika perlu ditangani secara khusus pula. Suherman (2003:57) menyatakan belajar matematika bagi para siswa juga merupakan pembentukan pola pikir dalam pemahaman suatu pengertian maupun penalaran suatu hubungan di antara pengertian-pengertian itu.

Menurut Sutarmo (2012:94) kemampuan berpikir kritis, otak dipaksa berpikir serius untuk memecahkan masalah yang dihadapi individu yang berpikir atau memikirkan tindakan yang akan dilakukan nanti. Karena setiap orang memiliki masalah yang bukan untuk dihindari melainkan untuk dipecahkan, maka seharusnya setiap orang juga memiliki kemampuan berpikir kritis sehingga mereka dapat memikirkan apa langkah yang harus ditempuh untuk memecahkan masalah serius yang mereka hadapi. Salah satu cara mengembangkan kemampuan berpikir kritis yaitu melalui pembelajaran matematika.

Solso (2007:136), menyatakan berpikir adalah proses yang membentuk representasi mental baru melalui transformasi informasi oleh interaksi kompleks dari atribut mental yang mencakup pertimbangan, pengabstrakan, penalaran, penggambaran, pemecahan masalah logis, pembentukan konsep kreativitas dan kecerdasan. Berpikir kritis adalah kemampuan berpikir reflektif yang berfokus pada pola pengambilan keputusan tentang apa yang harus diyakini dan harus dilakukan (Ennis, 2011). Siswa dituntut untuk dapat menganalisis, mensintesis dan menyimpulkan informasi-informasi yang didapatkan dengan kemampuan berpikir kritisnya, sehingga siswa mampu membedakan antara informasi yang baik dan buruk, serta dapat mengambil keputusan terhadap informasi yang didapatkannya melalui berpikir kritis.

Selain itu menurut Redhana dan Liliasari (2008), tujuan melatihkan kemampuan berpikir kritis kepada siswa adalah untuk menyiapkan siswa menjadi seorang pemikir kritis, mampu memecahkan masalah, dan menjadi pemikir independen, sehingga mereka dapat menghadapi kehidupan, menghindarkan diri dari indoktrinasi, penipuan, pencucian otak, mengatasi setiap masalah yang dihadapi, dan membuat keputusan dengan tepat dan bertanggung jawab.

Pembelajaran yang dilaksanakan oleh guru pada umumnya lebih menekankan pada aspek pengetahuan dan pemahaman sedangkan aspek aplikasi, analisis, evaluasi, dan bahkan kreasi hanya sebagian kecil dari pembelajaran yang dilakukan. Pembelajaran masih bersifat teacher orinted dan siswa kurang diberi kesempatan untuk mengembangkan kemampuan berpikir kritis. Hal ini menyebabkan siswa kurang terlatih untuk mengembangkan daya nalarnya dalam memecahkan permasalahan dan mengaplikasikan konsep-konsep yang telah dipelajari dalam kehidupan nyata sehingga kemampuan berpikir kritis siswa kurang dapat berkembang dengan baik (Masek dan Yamin, 2012). Selain itu, kondisi seperti ini juga menjadikan suasana pembelajaran kurang menarik, siswa cenderung menjadi penerima pasif, kurang responsif, kurang kreatif dan kritis, serta kurang memberikan pemahaman yang baik bagi siswa. Pembelajaran yang mengaktifkan siswa dapat meningkatkan hasil belajar, sebab pembelajaran aktif dapat memberi kesempatan kepada siswa untuk berlatih berpikir kritis (Freeman, 2007). Hasil penelitian Saefudin (2011), Syahbana (2012), dan Husnidar (2014) menunjukkan bahwa kemampuan berpikir kritis dalam meningkatkan kemampuan siswa dalam pembelajaran matematika. Pada pembelajaran matematika, siswa diajarkan untuk memperoleh pengetahuan melalui pengumpulan data dengan eksperimen, pengamatan, dan komunikasi untuk menghasilkan suatu penjelasan yang dapat dipercaya.

Terkait dengan pembelajaran matematika, perlu diperbaiki aktivitas pembelajaran di kelas oleh guru. Perlu dicari cara-cara baru untuk mendorong kegiatan pembelajaran lebih aktif, mampu meningkatkan solidaritas, dan mengoptimalkan keterlibatan siswa. Pemilihan strategi dan metode yang tepat dapat meningkatkan kemampuan berpikir siswa dan pada akhirnya akan berpengaruh terhadap hasil belajamya. Menurut Sanjaya (2005), tanpa suatu strategi yang cocok, tepat, dan jitu tidak mungkin tujuan tercapai. Oleh karena itu, guru seharusnya mampu mencari strategi yang dipandang dapat membelajarkan siswa melalui proses pengajaran yang dapat mencapai tujuan pembelajaran secara efektif dan hasil belajar diharapkan dapat lebih ditingkatkan.

Model pembelajaran think pair share merupakan salah satu model dari pembelajaran kooperatif yang paling 
sederhana, yang melibatkan siswa secara aktif belajar dalam suasana kelompok untuk memecahkan masalah belajar dan memiliki rasa tanggung jawab terhadap pembelajarannya sendiri dan juga pembelajaran orang lain (Getter dan Rowe, 2008). Siswa tidak hanya mempelajari materi yang diberikan, tetapi mereka juga harus siap dan bertanggung jawab memberikan maupun mengajarkan materi tersebut pada anggota kelompoknya yang lain (Nurhadi dan Senduk, 2003). Oleh karena itu, siswa saling tergantung satu dengan yang lain dan harus bekerja sama secara kooperatif untuk mempelajari materi yang ditugaskan. Model pembelajaran think pair share biasa digunakan dalam semua mata pelajaran dan untuk semua tingkatan usia anak didik (Lie, 2008).

Model pembelajaran kooperatif think pair share, memberi kesempatan kepada siswa bekerja sendiri (thinking) sehingga memupuk sifat lebih mandiri dalam mengerjakan soal yang diberikan dan juga menimbulkan sifat bekerja sama dengan orang lain dalam kelompok kecil (pairing) sehingga membangkitkan rasa percaya diri siswa. Dalam hal ini optimalisasi partisipasi siswa dapat terlihat sehingga muncul jawaban-jawaban secara spontan yang bisa memberikan kontribusi pada kelompok yang sedang dihadapinya. Sehingga di sini guru berperan sebagai pembimbing, fasilitator, dan motivator. Siswa yang kesulitan akan tertolong dan materi yang sulit akan lebih mudah untuk dipahami siswa sehingga ketuntasan dalam proses pembelajaran dapat tercapai.

Selain strategi pembelajaran kooperatif tipe think pair share, salah satu strategi pembelajaran yang dapat dikedapankan adalah pembelajaran kooperatif tipe jigsaw. Hasil penelitian Palennari (2011) menyatakan pembelajaran dengan tipe kooperatif Jigsaw dapat meningkatkan pemahaman konsep. Hasil penelitian Sugianto, dkk (2014) mengemukakan model pembelajaran kooperatif tipe Jigsaw dapat meningkatkan komunikasi matematis siswa. Dengan model pembelajaran kooperatif tipe Jigsaw, kemampuan matematika siswa meningkat yang terlihat dari: (1) menghubungkan benda nyata, gambar, dan diagram ke dalam idea matematika; (2) menjelaskan ide, situasi, dan relasi matematik, secara lisan dan tulisan dengan benda nyata, gambar, grafik dan aljabar; (3) menyatakan peristiwa sehari-hari dalam bahasa atau simbol matematika; (4) mendengarkan, berdiskusi, dan menulis tentang matematika; (5) membaca dengan pemahaman suatu presentasi Matematika tertulis; (6) membuat konjektur, menyusun argumen, merumuskan definisi dan generalisasi; dan (7) menjelaskan dan membuat pertanyaan matematika yang telah dipelajari.

Keuntungan model pembelajaran koorperatif tipe jigsaw adalah adanya kerjasama dalam kelompok dan dalam menentukan keberhasilan kelompok tergantung keberhasilan individu, sehingga setiap anggota kelompok tidak bisa mengantungkan diri pada anggota yang lain. Dengan demikian, setiap individu merasa mendapat tugas dan tanggung jawab sendiri-sendiri, sehingga tujuan pembelajaran kooperatif dapat bermakna dan sesuai dengan harapan.

Selain itu diharapkan dengan penggunaan model pembelajaran kooperatif tipe jigsaw, siswa dapat bekerja sama mengidentifikasi dan memahami materi matematika, serta memecahkan permasalahan dalam pembelajaran matematika. Kegiatan pembelajaran ini diawali oleh pembagian kelompok, kemudian guru menyajikan garis besar materi pelajaran, lalu siswa memdapatkan tugas masing-masing, siswa yang mendapat tugas yang sama akan berkumpul dan mendiskusikan tugasnya, setelah selesai mereka kembali ke kelompoknya untuk menyampaikan hasil pekerjaannya kepada temannya.

Mengacu pada pendekatan di atas maka pola kegiatan proses pembelajaran perlu dicoba untuk disesuaikan dengan konteks interaksi antara guru dengan siswa agar suasana pembelajaran di dalam kelas dapat bergairah dan siswa tidak lagi pasif tetapi ada kecenderungan untuk berpartisipasi aktif dalam pembelajaran matematika. Kondisi pembelajaran yang demikian menuntut guru agar dapat memilih model pembelajaran yang tepat, agar siswa dapat meningkatkan kemampuannya dalam memahami materi matematika. Selama ini guru hanya menggunakan model pembelajaran konvensional, sehingga siswa hanya sebagai objek banyak bersikap pasif dan tidak banyak berbuat. Akhirnya guru dituntut untuk memilih model pembelajaran yang yang menuntuk siswa lebih aktif, kreatif, inovatif dan menyenangkan.

\section{B. METODE PENELITIAN}

Penelitian ini akan dilaksanakan di SD Muhammadiyah 12 Medan yang beralamat di Jalan Kapten Muslim Gg. Jawa - Kota Medan. Waktu penelitian dilaksanakan pada semester genap tahun pelajaran 2014/2015 bulan Januari - Juni 2015.

Populasi dalam penelitian ini adalah seluruh siswa kelas VI SD Muhammadiyah 12 Medan tahun pelajaran 2014/2015 sebanyak 3 kelas yang berjumlah 78 siswa. Sampel penelitian ini diambil atau ditentukan dengan teknik Random Sampling. Berdasarkan Random Sampling diperoleh kelas VI-1 sebagai kelas eksperimen pertama dengan pembelajaran kooperatif tipe think pair share, kelas VI-3 sebagai kelas eksperimen kedua dengan pembelajaran kooperatif tipe jigsaw, dan kelas VI-2 sebagai kelas kontrol dengan pembelajaran konvensional.

Penelitian ini termasuk jenis penelitian quasi eksperimen. Dalam penelitian ini terdapat tiga kelompok sampel yang diteliti yaitu dua kelompok eksperimen dan satu kelompok kontrol. Desain yang digunakan dalam penelitian ini dengan desain pretest-posttest control group design untuk hasil belajar siswa. Dalam penelitian ini terdapat 3 kelompok perlakuan yaitu kelompok pertama dengan pembelajaran kooperatif tipe think pair share, kelompok kedua dengan pembelajaran kooperatif tipe jigsaw, dan kelompok tiga dengan pembelajaran konvensional. Sebelum perlakuan diberikan, terlebih dahulu ditinjau faktor-faktor kesamaan dari tiga kelompok eksperimen, yaitu kesamaan yang mempengaruhi pelaksanaan kegiatan belajar mengajar. Hal ini bertujuan untuk meyakinkan bahwa kedua kelas eksperimen dan satu kelas kontrol mempunyai karakteristik yang sama. Faktor-faktor yang dapat mempengaruhi kegiatan belajar mengajar antara lain adalah tujuan pembelajaran, guru, siswa, situasi dan kondisi kelas, dan metode pembelajaran.

Definisi operasional variabel dibatasi sebagai berikut:

1. Strategi pembelajaran kooperatif tipe think pair share merupakan salah satu strategi pembelajaran kelompok yang melibatkan siswa secara aktif belajar dalam suasana kelompok kecil yang terdiri dari dua orang yang saling bekerja sama untuk memecahkan masalah. 
2. Strategi pembelajaran kooperatif tipe jigsaw merupakan pembelajaran dalam bentuk kelompok di kelas dengan tujuan meningkatkan partisipasi siswa, memfasilitasi siswa dengan pengalaman belajar kelompok, dan memberikan kesempatan berinteraksi dengan siswa lainnya untuk mencapai tujuan belajar secara bersama-sama.

3. Pembelajaran konvensional merupakan pembelajaran dengan guru sebagai sumber pembelajaran utama dalam menyalurkan pengetahuan kepada siswa, dimana siswa diharuskan untuk belajar sendiri dalam keadaan kelas yang tenang. Pada pembelajaran ini guru memberikan penjelasan secara lisan kepada siswa, siswa mendengar dan mencatat seperlunya.

4. Kemampuan berpikir kritis merupakan proses berpikir yang memungkinkan siswa untuk menganalisis argumen dan memunculkan wawasan terhadap tiaptiap makna dan interpretasi untuk mengembangkan pola penalaran yang kohesif dan logis.

5. Hasil belajar matematika merupakan kemampuan kognitif siswa dalam mata pelajaran matematika menurut ranah Taksonomi Bloom meliputi aspek C1, C2, C3, dan C4. Tingkat keberhasilan siswa dalam mempelajari materi menghitung luas dan volume diukur dalam bentuk skor yang diperoleh dari hasil tes.

Teknik analisis data yang digunakan dalam penelitian ini adalah analisis deskriftif dan analisis inferensial. Analisis deskriptif dimaksudkan untuk mendeskripsikan data penelitian berupa data hasil belajar siswa pada materi pokok menghitung luas dan volume di kelas VI SD Muhammadiyah 12 Medan. Analisis deskriptif digunakan untuk menafsirkan data yang diperoleh di lapangan setelah dianalisis inferensial dideskripsikan melalui analisis deskriptif, dan dijabarkan sehingga diperoleh kesimpulan mengenai pengaruh strategi pembelajaran kooperatif tipe think pair share dan strategi pembelajaran kooperatif tipe jigsaw terhadap kemampuan berpikir kritis dan hasil belajar matematika siswa di SD Muhammadiyah 12 Medan. Sedangkan analisis statistik inferensial dilakukan untuk menguji hipotesis. Pengujian hipotesis penelitian, untuk data hasil belajar dan kemampuan berpikir kritis siswa dianalisis dengan menggunakan teknik Analisis Kovariat (Anacova) pada taraf $\alpha=5 \%$. Analisis dilakukan dengan menggunakan program SPSS 18.0 for windows.

\section{HASIL}

\section{Deskripsi Data Kemampuan Berpikir Kritis Siswa}

Hasil pretes, menunjukkan bahwa kemampuan berpikir kritis siswa kelas strategi pembelajaran kooperatif tipe think pair share diperoleh nilai tertinggi sebesar 69 dan nilai terendah 21 dengan rata-rata 38,333 dan standar deviasi 14,565. Dari hasil uji normalitas dengan menggunakan Kolmogorov-Smirnov disimpulkan bahwa data pretes kemampuan berpikir kritis siswa kelas strategi pembelajaran kooperatif tipe think pair share memiliki sebaran data yang berdistribusi normal dengan $\mathrm{Z}$ $=0,729$ dan $P=0,662$. Pada kelas perlakuan dengan strategi pembelajaran kooperatif tipe jigsaw diperoleh nilai tertinggi sebesar 67 dan nilai terendah 18 dengan rata-rata 39,680 dan standar deviasi 14,693. Dari hasil uji normalitas dengan menggunakan Kolmogorov-Smirnov disimpulkan bahwa data pretes kemampuan berpikir kritis siswa kelas perlakuan dengan strategi pembelajaran kooperatif tipe jigsaw memiliki sebaran data yang berdistribusi normal dengan $\mathrm{Z}=0,792$ dan $\mathrm{P}=0,556$. Sementara pada kelas konvensional diperoleh nilai tertinggi sebesar 71 dan nilai terendah 18 dengan ratarata 41,069 dan standar deviasi 14,643. Dari hasil uji normalitas dengan menggunakan Kolmogorov-Smirnov disimpulkan bahwa data pretes kemampuan berpikir kritis siswa kelas konvensional memiliki sebaran data yang berdistribusi normal dengan $\mathrm{Z}=0,820$ dan $\mathrm{P}=0,512$.

Hasil postes, menunjukkan bahwa kemampuan berpikir kritis siswa kelas strategi pembelajaran kooperatif tipe think pair share diperoleh nilai tertinggi sebesar 94 dan nilai terendah 51 dengan rata-rata 76,792 dan standar deviasi 11,788. Dari hasil uji normalitas dengan menggunakan Kolmogorov-Smirnov disimpulkan bahwa data postes kemampuan berpikir kritis siswa kelas strategi pembelajaran kooperatif tipe think pair share memiliki sebaran data yang berdistribusi normal dengan $\mathrm{Z}$ $=1,053$ dan $\mathrm{P}=0,218$. Pada kelas perlakuan dengan strategi pembelajaran kooperatif tipe jigsaw diperoleh nilai tertinggi sebesar 85 dan nilai terendah 55 dengan rata-rata 74,320 dan standar deviasi 8,494. Dari hasil uji normalitas dengan menggunakan Kolmogorov-Smirnov disimpulkan bahwa data postes kemampuan berpikir kritis siswa kelas perlakuan dengan strategi pembelajaran kooperatif tipe jigsaw memiliki sebaran data yang berdistribusi normal dengan $\mathrm{Z}=0,921$ dan $\mathrm{P}=0,365$. Sementara pada kelas konvensional diperoleh nilai tertinggi sebesar 82 dan nilai terendah 33 dengan ratarata 66,069 dan standar deviasi 13,944. Dari hasil uji normalitas dengan menggunakan Kolmogorov-Smirnov disimpulkan bahwa data postes kemampuan berpikir kritis siswa kelas konvensional memiliki sebaran data yang berdistribusi normal dengan $\mathrm{Z}=1,124$ dan $\mathrm{P}=0,160$ )

Selanjutnya hasil uji homogenitas data kemampuan berpikir kritis siswa dengan menggunakan uji Levene's Test menunjukkan variasi data antara ketiga kelompok sampel dalam populasi adalah homogen dengan $\mathrm{F}=1,535$ dan $\mathrm{P}=0,134$.

\section{Deskripsi Data Hasil Belajar Siswa}

Hasil pretes, menunjukkan bahwa hasil belajar siswa kelas strategi pembelajaran kooperatif tipe think pair share diperoleh nilai tertinggi sebesar 40 dan nilai terendah 15 dengan rata-rata 26,667 dan standar deviasi 6,703. Dari hasil uji normalitas dengan menggunakan Kolmogorov-Smirnov disimpulkan bahwa data pretes hasil belajar siswa kelas strategi pembelajaran kooperatif tipe think pair share memiliki sebaran data yang berdistribusi normal dengan $\mathrm{Z}=0,612$ dan $\mathrm{P}=0,847$. Pada kelas perlakuan dengan strategi pembelajaran kooperatif tipe jigsaw diperoleh nilai tertinggi sebesar 40 dan nilai terendah 15 dengan rata-rata 28,000 dan standar deviasi 6,904. Dari hasil uji normalitas dengan menggunakan Kolmogorov-Smirnov disimpulkan bahwa data pretes hasil belajar siswa kelas perlakuan dengan strategi pembelajaran kooperatif tipe jigsaw memiliki sebaran data yang berdistribusi normal dengan $\mathrm{Z}=0,540$ dan $\mathrm{P}=0,933$. Sementara pada kelas konvensional diperoleh nilai tertinggi sebesar 40 dan nilai terendah 15 dengan ratarata 27,586 dan standar deviasi 7,395. Dari hasil uji normalitas dengan menggunakan Kolmogorov-Smirnov 
disimpulkan bahwa data pretes hasil belajar siswa kelas konvensional memiliki sebaran data yang berdistribusi normal dengan $\mathrm{Z}=0,717$ dan $\mathrm{P}=0,683$.

Hasil postes, menunjukkan bahwa hasil belajar siswa kelas strategi pembelajaran kooperatif tipe think pair share diperoleh nilai tertinggi sebesar 90 dan nilai terendah 60 dengan rata-rata 80,625 dan standar deviasi 7,706. Dari hasil uji normalitas dengan menggunakan Kolmogorov-Smirnov disimpulkan bahwa data postes hasil belajar siswa kelas strategi pembelajaran kooperatif tipe think pair share memiliki sebaran data yang berdistribusi normal dengan $\mathrm{Z}=0,914$ dan $\mathrm{P}=0,373$. Pada kelas perlakuan dengan strategi pembelajaran kooperatif tipe jigsaw diperoleh nilai tertinggi sebesar 95 dan nilai terendah 60 dengan rata-rata 79,000 dan standar deviasi 9,014. Dari hasil uji normalitas dengan menggunakan Kolmogorov-Smirnov disimpulkan bahwa data postes hasil belajar siswa kelas perlakuan dengan strategi pembelajaran kooperatif tipe jigsaw memiliki sebaran data yang berdistribusi normal dengan $\mathrm{Z}=0,900$ dan $\mathrm{P}=0,393$.
Sementara pada kelas konvensional diperoleh nilai tertinggi sebesar 80 dan nilai terendah 55 dengan ratarata 69,310 dan standar deviasi 6,908. Dari hasil uji normalitas dengan menggunakan Kolmogorov-Smirnov disimpulkan bahwa data postes hasil belajar siswa kelas konvensional memiliki sebaran data yang berdistribusi normal dengan $\mathrm{Z}=0,926$ dan $\mathrm{P}=0,358$.

Selanjutnya hasil uji homogenitas data hasil belajar siswa dengan menggunakan uji Levene's Test menunjukkan variasi data antara ketiga kelompok sampel dalam populasi adalah homogen dengan $\mathrm{F}=0,450$ dan $\mathrm{P}=0,640$.

\section{Hasil Penelitian}

\section{Pengaruh Strategi Pembelajaran Terhadap Kemampuan Berpikir Kritis Siswa}

Hasil analisis varians (ANAVA) dengan bantuan SPSS 18.0 menunjukkan bahwa strategi pembelajaran secara signifikan berpengaruh terhadap kemampuan berpikir

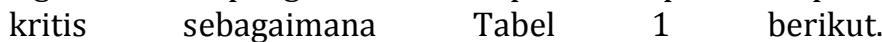

TABEL 1.

PERHITUNGAN ANAVA STRATEGI PEMBELAJARAN TERHADAP KEMAMPUAN BERPIKIR KRITIS

\begin{tabular}{|l|r|r|r|r|l|}
\hline & Sum of Squares & \multicolumn{1}{c|}{ df } & Mean Square & F & Sig. \\
\hline Between Groups & 6,817 & 2 & 3,408 & 9,067 &, 006 \\
Within Groups & 3837,799 & 75 & 51,171 & & \\
Total & 3844,615 & 77 & & & \\
\hline
\end{tabular}

Berdasarkan Tabel 1 di atas, diperoleh bahwa besar $F_{\text {hitung }}=9,067$ dengan $p=0,006$. Dengan demikian dapat disimpulkan bahwa kemampuan berpikir kritis siswa dapat dipengaruhi oleh strategi pembelajaran yang digunakan guru. Selanjutnya untuk mellihat perbedaan kemampuan berpikir kritis setiap kelas perlakuan dilakukan perhitungan lanjutan dengan Uji Tukey sebagaimana hasil pada Tabel 2 berikut.

TABEL 2.

UJI LANJUT STRATEGI PEMBELAJARAN TERHADAP KEMAMPUAN BERPIKIR KRITIS

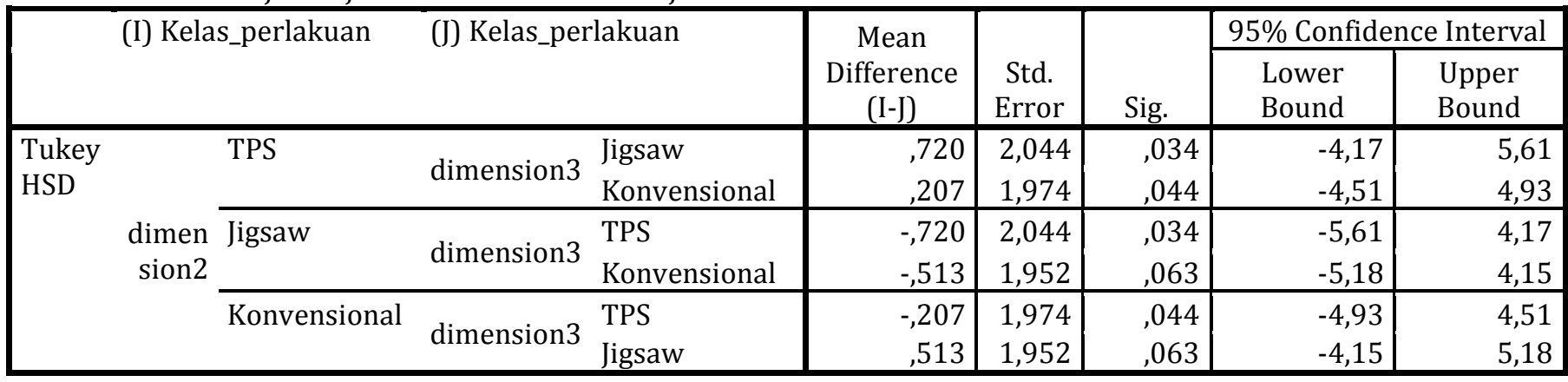

Dari Tabel 2 di atas disimpulkan bahwa strategi pembelajaran think pair share lebih baik daripada strategi pembelajaran jigsaw dan pembelajaran konvensional dalam meningkatkan kemampuan berpikir kritis. Dari Tabel 4.4 juga diperoleh: (1) terdapat perbedaan rata-rata yang signifikan pada kemampuan berpikir kritis antara strategi pembelajaran think pair share dengan strategi pembelajaran jigsaw sebesar 2,044 dengan taraf signifikansi 0,034; (2) terdapat perbedaan rata-rata yang signifikan pada kemampuan berpikir kritis antara strategi pembelajaran think pair share dengan strategi pembelajaran konvensional sebesar 1,974 dengan taraf signifikansi 0,044; dan (3) tidak terdapat perbedaan ratarata yang signifikan pada kemampuan berpikir kritis antara strategi pembelajaran jigsaw dengan strategi pembelajaran konvensional sebesar 1,952 dengan taraf signifikansi 0,063.

Dengan demikian dapat disimpulkan bahwa kemampuan berpikir kritis siswa yang dibelajarkan dengan strategi pembelajaran kooperatif tipe think pair share secara signifikan lebih tinggi dibandingkan kemampuan berpikir kritis siswa yang dibelajarkan dengan strategi pembelajaran kooperatif tipe jigsaw dan yang dibelajarkan dengan strategi konvensional. Selengkapnya dapat dilihat pada Gambar 1 berikut.

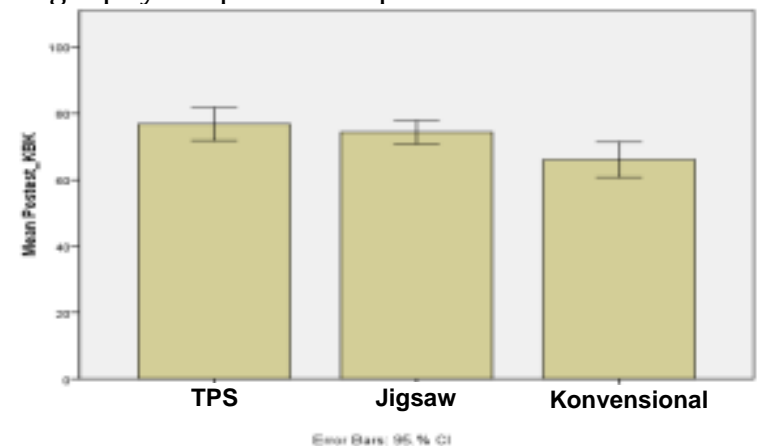

Gambar 1. Pengaruh Strategi Pembelajaran Terhadap Kemampuan Berpikir Kritis Siswa 


\section{Pengaruh Strategi Pembelajaran terhadap Hasil Belajar Matematika}

Strategi pembelajaran secara signifikan berpengaruh terhadap hasil belajar matematika sebagaimana Tabel 3 berikut.

TABEL 3.

PERHITUNGAN ANAVA STRATEGI PEMBELAJARAN TERHADAP HASIL BELAJAR MATEMATIKA

ANOVA

Hasil_belajar_matematika

\begin{tabular}{|l|c|r|r|r|l|}
\hline & $\begin{array}{c}\text { Sum of } \\
\text { Squares }\end{array}$ & df & $\begin{array}{c}\text { Mean } \\
\text { Square }\end{array}$ & F & Sig. \\
\hline $\begin{array}{l}\text { Between } \\
\text { Groups }\end{array}$ & 1150,474 & 2 & 575,23 & 11,1 &, 000 \\
Within & 3880,872 & 75 & 51,745 & 17 & \\
Groups & & & & & \\
Total & 5031,346 & 77 & & & \\
\hline
\end{tabular}

Berdasarkan Tabel 3 di samping, diperoleh bahwa besar Fhitung $=11,117$ dengan $p=0,000$. Dengan demikian dapat disimpulkan bahwa hasil belajar Matematika dapat dipengaruhi oleh strategi pembelajaran yang digunakan guru. Selanjutnya untuk mellihat perbedaan hasil belajar Matematika setiap kelas perlakuan dilakukan perhitungan lanjutan dengan Uji Tukey sebagaimana hasil pada Tabel 4 berikut.

TABEL 4.

UJI LANJUT STRATEGI PEMBELAJARAN TERHADAP HASIL BELAJAR MATEMATIKA Multiple Comparisons

Dependent Variable:Hasil_belajar_matematika

\begin{tabular}{|c|c|c|c|c|c|c|c|c|c|}
\hline & \multirow{2}{*}{\multicolumn{2}{|c|}{ (I) Kelas_perlakuan }} & \multirow{2}{*}{\multicolumn{2}{|c|}{ (J) Kelas_perlakuan }} & \multirow{2}{*}{$\begin{array}{c}\text { Mean } \\
\text { Differenc } \\
\text { e (I-J) }\end{array}$} & \multirow[b]{2}{*}{$\begin{array}{l}\text { Std. } \\
\text { Error }\end{array}$} & \multirow[b]{2}{*}{ Sig. } & \multicolumn{2}{|c|}{$\begin{array}{l}\text { 95\% Confidence } \\
\text { Interval }\end{array}$} \\
\hline & & & & & & & & $\begin{array}{l}\text { Lower } \\
\text { Bound }\end{array}$ & $\begin{array}{l}\text { Upper } \\
\text { Bound }\end{array}$ \\
\hline \multirow{6}{*}{$\begin{array}{l}\text { Tukey } \\
\text { HSD }\end{array}$} & \multirow{6}{*}{ dimension2 } & \multirow[t]{2}{*}{ TPS } & \multirow{2}{*}{ dimension3 } & Jigsaw & $5,905^{*}$ & 2,056 & 014 & ,99 & 10,82 \\
\hline & & & & Konvensional & $9,315^{*}$ & 1,985 & ,000 & 4,57 & 14,06 \\
\hline & & \multirow[t]{2}{*}{ Jigsaw } & \multirow{2}{*}{ dimension3 } & TPS & $-5,905^{*}$ & 2,056 & 014 & $-10,82$ &,- 99 \\
\hline & & & & Konvensional & 3,410 & 1,963 & 198 & $-1,28$ & 8,10 \\
\hline & & \multirow[t]{2}{*}{ Konvensional } & \multirow{2}{*}{ dimension3 } & TPS & $-9,315^{*}$ & 1,985 & ,000 & $-14,06$ & $-4,57$ \\
\hline & & & & Jigsaw & $-3,410$ & 1,963 & 198 & $-8,10$ & 1,28 \\
\hline
\end{tabular}

*. The mean difference is significant at the 0.05 level.

Dari Tabel 4 di atas disimpulkan bahwa strategi pembelajaran think pair share lebih baik daripada strategi pembelajaran jigsaw dan pembelajaran konvensional dalam meningkatkan hasil belajar matematika. Dari Tabel 4.4 juga diperoleh: (1) terdapat perbedaan rata-rata yang signifikan pada hasil belajar Matematika antara strategi pembelajaran think pair share dengan strategi pembelajaran jigsaw sebesar 5,905 dengan taraf signifikansi 0,014 ; (2) terdapat perbedaan rata-rata yang signifikan pada hasil belajar Matematika antara strategi pembelajaran think pair share dengan strategi pembelajaran konvensional sebesar 9,315 dengan taraf signifikansi 0,000; dan (3) tidak terdapat perbedaan ratarata yang signifikan pada hasil belajar Matematika antara strategi pembelajaran jigsaw dengan strategi pembelajaran konvensional sebesar 3,410 dengan taraf signifikansi 0,198.

Dengan demikian dapat disimpulkan bahwa hasil belajar siswa yang dibelajarkan dengan strategi pembelajaran kooperatif tipe think pair share secara signifikan lebih tinggi dibandingkan hasil belajar yang dibelajarkan dengan strategi pembelajaran kooperatif tipe jigsaw dan yang dibelajarkan dengan strategi konvensional. Selengkapnya dapat dilihat pada Gambar 2 berikut.

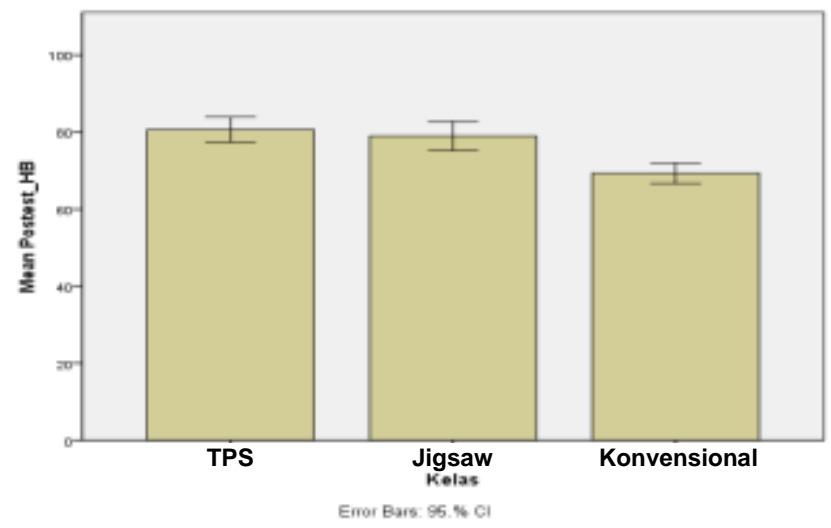

Gambar 2. Pengaruh Strategi Pembelajaran Terhadap Hasil Belajar Matematika pada Pokok Bahasan Menghitung Luas dan Volume Kelas VI SD Muhammadiyah 12 Medan

\section{PEMBAHASAN}

\section{Pengaruh Strategi Pembelajaran terhadap Kemampuan Berpikir Kritis Siswa}

Strategi pembelajaran kooperatif tipe think pair share merupakan salah satu strategi pembelajaran kelompok yang melibatkan siswa secara aktif belajar dalam suasana kelompok kecil yang terdiri dari dua orang yang saling bekerja sama untuk memecahkan masalah. Dengan demikian, pembelajaran strategi pembelajaran kooperatif 
tipe think pair share memberikan tekanan pada terselesaikannya suatu masalah secara bernalar.

Hasil penelitian ini mendukung penelitian Klegeris, et. al. (2011) bahwa kemampuan memecahkan masalah siswa yang membaik setelah mereka diberikan pembelajaran strategi pembelajaran kooperatif tipe think pair share pada kelas besar. Penelitian ini menunjukkan peningkatan keterlibatan siswa yang diberikan dengan pembelajaran strategi pembelajaran kooperatif tipe think pair share dibandingkan dengan pembelajaran konvensional. Hasil penelitian Getter dan Rowe (2008) mengungkapkan bahwa dengan strategi pembelajaran think pair share sebagian besar siswa (91,5\%) menunjukkan bahwa dengan pembelajaran think pair share lebih siap untuk memecahkan masalah. Penelitian Ibe (2009) juga mengungkapkan bahwa terdapat pengaruh strategi pembelajaran pembelajaran kooperatif tipe think pair share terhadap prestasi belajar. Dalam penelitian ini disimpulkan bahwa strategi pembelajaran pembelajaran kooperatif sebagai strategi pembelajaran pembelajaran yang lebih aktif dan efektif untuk mengkonstruksi pengetahuan yang bisa mengakomodasi terlaksananya keterampilan proses sains ternyata secara signifikan mampu meningkatkan perolehan nilai prestasi belajar siswa. Dengan pembelajaran strategi pembelajaran kooperatif tipe think pair share, siswa terdorong untuk melakukan penyelidikan dan membahas isu-isu pelajaran yang diidentifikasi dalam kelompok dengan guru sebagai fasilitator dan pelatih.

Arends (2008) menyatakan bahwa pembelajaran strategi pembelajaran kooperatif tipe think pair share membantu siswa untuk mengembangkan keterampilan berpikir dan keterampilan mengatasi masalah, mempelajari peran-peran orang dewasa dan menjadi pelajar yang mandiri. Dalam strategi pembelajaran kooperatif tipe think pair share, terdapat proses pembelajaran bukan memorisasi kumpulan informasi tertentu yang perlu ditekankan. Siswa bekerja dalam kelompok kelompok kecil secara koperatif untuk menangani masalah dengan cara analisis. Oleh karena itu, pembelajaran strategi pembelajaran kooperatif tipe think pair share dapat meningkatkan keterampilan berpikir lebih tinggi selama proses menangani masalah-masalah sulit. Dalam pembelajaran strategi pembelajaran kooperatif tipe think pair share, siswa dianggap sebagai konstruktor pengetahuan, sehingga pemikiran kritis sangat dianjurkan. Pembelajaran pemecahan masalah mendukung perkembangan keterampilan yang penting untuk dievaluasi kritis dan perolehan pengetahuan baru.

Matematika merupakan mata pelajaran yang mempunyai objek kajian abstrak, berupa fakta, konsep, operasi dan prinsip. Mempelajari hakekat matematika berarti meninjau apa sebenarnya belajar matematika itu, baik dalam arti katanya maupun peranan dan kedudukannya di antara cabang ilmu lainnya. Sampai saat ini pengertian matematika belum mempunyai defenisi secara jelas. Permasalahan terkait gagasan dan pengetahuan yang disampaikan secara matematis dapat diselesaikan dengan prosedur formal matematika yang langkahnya sangat presisi dan tidak terbantahkan. Karenanya matematika berperan sebagai alat komunikasi formal paling efisien. Perlu kemampuan berpikir kritiskreatif untuk menggunakan matematika untuk: menentukan variabel dan parameter, mencari keterkaitan antar variabel dan dengan parameter.

Untuk itu, dalam menyelesaikan suatu permasalahan tersebut diperlukan adanya metode ilmiah secara sistematis. Proses belajar tidak hanya menekankan pada aspek mengingat pengetahuan dan pemahaman, namun juga aspek aplikasi, analisis, evaluasi, dan kreativitas. Hal ini penting karena siswa dapat melatih berpikir dan memecahkan masalah serta pengaplikasian konsep dalam kehidupan sehari-hari. Oleh karena itu, diperlukan penerapan pembelajaran yang mampu menciptakan suasana belajar siswa yang aktif, memupuk kerjasama antar siswa, serta melatih kemampuan belajar siswa sehingga dapat memecahkan masalah yakni melalui strategi pembelajaran kooperatif kooperatif tipe think pair share.

Dalam pembelajaran di kelas guru dapat melakukan perencanaan pembelajaran terlebih dahulu dengan mengkonfrontasikan materi pelajaran dengan masalah real di lapangan. Dengan cara ini guru dapat memberitahu siswa tentang untuk apa mereka belajar, serta informasi apa yang akan mereka dapatkan dari pelajaran yang akan diberikan. Untuk itu guru harus dapat merancang pembelajaran kooperatif tipe think pair share dengan langkah-langkah: (1) Fase 1: Think. Guru mengajukan pertanyaan atau isu yang berhubungan dengan pelajaran. Kemudian siswa diminta untuk memikirkan pertanyaan atau isu tersebut secara mandiri untuk beberapa saat; (2) Fase 2: Pair. Guru meminta siswa berpasangan dengan siswa lain untuk mendiskusikan apa yang telah dipikirkannya pada tahap pertama. Dalam tahap ini, setiap anggota pada kelompok membandingkan jawaban atau hasil pemikiran mereka dengan mendefinisikan jawaban yang dianggap paling benar, paling meyakinkan, atau paling unik. Biasanya guru memberi waktu 4-5 menit untuk berpasangan; dan (3) Fase 3: Share. Pada tahap akhir, guru meminta kepada pasangan untuk berbagi dengan seluruh kelas tentang apa yang telah mereka bicarakan. Keterampilan berbagi dalam seluruh kelas dapat dilakukan dengan menunjuk pasangan yang secara sukarela bersedia melaporkan hasil kerja kelompoknya atau bergiliran pasangan demi pasangan hingga sekitar seperempat pasangan telah mendapat kesempatan untuk melaporkan.

Selain pembelajaran strategi pembelajaran kooperatif tipe think pair share, guru juga dapat menggunakan strategi pembelajaran kooperatif tipe jigsaw. Strategi pembelajaran kooperatif tipe jigsaw merupakan pembelajaran dalam bentuk kelompok di kelas dengan tujuan meningkatkan partisipasi siswa, memfasilitasi siswa dengan pengalaman belajar kelompok, dan memberikan kesempatan berinteraksi dengan siswa lainnya untuk mencapai tujuan belajar secara bersamasama.

Dalam hal ini, strategi pembelajaran kooperatif tipe jigsaw dapat memberikan kesempatan kepada siswa untuk menemukan ide pokok, untuk saling berpikir kemudian dibahas bersama. Siswa juga diberi kesempatan untuk saling mengajarkan kepada teman lain dalam kelompoknya dan saling mentransfer ilmu pengetahuannya. Untuk itu guru harus dapat merancang pembelajaran kooperatif tipe jigsaw dengan langkahlangkah: (1) Orientasi dilakukan guru menyampaikan tujuan pembelajaran yang akan diberikan. Siswa diminta 
belajar konsep secara keseluruhan secara untuk memperoleh gambaran keseluruhan dari konsep; (2) Pengelompokan siswa terkait kemampuan matematikanya mulai kelompok sangat baik, baik, sedang, dan rendah; (3) Pembentukan dan pembinaan kelompok expert; (4) Diskusi (pemaparan) kelompok ahli dalam grup. Dengan proses ini diharapkan terjadi shearing pengetahuan antara mereka; (5) Tes (penilaian). Pada fase ini guru memberikan tes tulis untuk dikerjakan oleh siswa memuat seluruh konsep yang didiskusikan; dan (6) Pengakuan Kelompok. Penilaian pada model pembelajaran kooperatif tipe jigsaw didasarkan pada seberapa jauh skor yang dicapai siswa melampaui rata-rata skor sebelumnya.

Dengan penerapan strategi pembelajaran kooperatif kooperatif tipe jigsaw dan strategi pembelajaran think pair share, maka diduga bahwa kemampuan siswa dalam berpikir kritis akan lebih meningkat. Jika siswa memiliki kemampuan berpikir baik maka penguasaan konsep dalam pengetahuan akan lebih baik. Peningkatan kemampuan berpikir ini berdampak pada peningkatan hasil belajar kognitif siswa.

\section{Pengaruh Strategi Pembelajaran terhadap Hasil Belajar Siswa}

Materi pelajaran matematika merupakan pelajaran yang sangat kompleks dan sangat dibutuhkan dalam kehidupan sehari-hari, karena matematika merupakan ilmu dasar yang timbul karena adanya aktivitas manusia. Konsep-konsep dalam matematika saling berkaitan satu dengan yang lainnya membentuk struktur yang tersusun secara hierarkis artinya suatu konsep merupakan konsep yang mendasari konsep lainnya. Sehingga apabila ada siswa yang kesulitan dalam memahami sebuah konsep dan konsep tersebut mendasari konsep berikutnya maka kemungkinan siswa gagal memahami konsep baru tersebut.

Untuk itu, dalam pembelajaran matematika di kelas seorang guru harus dapat menggunakan strategi pembelajaran yang tepat sesuai materi dan kemampuan berpikir siswa-siswanya. Salah satu strategi pembelajaran yang dapat digunakan guru adalah strategi pembelajaran kooperatif tipe think pair share dan tipe jigsaw. Hasil penelitian ini mendukung penelitian Sungur, et. al. (2006) tentang pengaruh pembelajaran strategi pembelajaran kooperatif tipe think pair share, terhadap prestasi dan kemampuan belajar siswa pada materi pokok menghitung luas dan volume. Hasil penelitian Kolber (2011) menyatakan siswa yang dibelajarkan dengan strategi strategi pembelajaran kooperatif tipe think pair share, berhasil dalam mencapai tujuan yang telah ditetapkan. Secara khusus, siswa berhasil diperkenalkan dengan proses ilmiah melalui penelitian strategi pembelajaran kooperatif tipe think pair share, dengan menunjukkan peningkatan dalam keterampilan presentasi mereka dan memiliki kesempatan untuk mengembangkan keterampilan mereka bekerja dalam kelompok. Hasil penelitian Syafii dan Yasin (2013) menyatakan strategi pembelajaran kooperatif tipe think pair share menunjukkan bahwa dapat meningkatkan keterampilan pemecahan masalah, prestasi, dan hasil belajar siswa.

Strategi yang dapat diterapkan guru untuk meningkatkan hasil belajar siswa dalam belajar matematika salah satunya dengan strategi pembelajaran kooperatif tipe think pair share. Strategi pembelajaran kooperatif tipe think pair share merupakan strategi pembelajaran yang menggunakan masalah dunia nyata sebagai suatu konteks bagi siswa untuk belajar tentang cara berpikir kritis dan keterampilan pemecahan masalah, serta untuk memperoleh pengetahuan dan konsep yang esensial dari materi pelajaran. Peran guru dalam pembelajaran strategi pembelajaran kooperatif tipe think pair share adalah memberikan masalah, mengajukan pertanyaan, dan memfasilitasi penyelidikan dan dialog. Dengan demikian, penerapan strategi pembelajaran kooperatif tipe think pair share, maka diduga bahwa hasil belajar siswa akan lebih meningkat.

Dalam strategi pembelajaran kooperatif kooperatif tipe think pair share, guru berperan sebagai fasilitator seperti layaknya tim yang bekerjasama dengan siswa dalam menggali sumber-sumber informasi. Guru bertugas membentuk siswa untuk mencapai tujuan pembelajaran melalui serangkaian upaya atau siasat yang mendorong siswa untuk terlibat aktif dalam mengkonstruk sendiri pengetahuan yang diinginkan siswa, dengan demikian siswa diberdayakan seoptimal mungkin karena terlibat secara aktif dalam mengkonstruk sendiri konsep, pengetahuan dan keterampilan matematika yang ditemukan dengan apa yang dimilikinya.

Hal ini senada disampaikan oleh Chin dan Li-gek (2008), bahwa pembelajaran kooperatif merupakan suatu cara yang efektif untuk mempromosikan pembelajaran "student center" di kelas. Hal ini disebabkan karena pembelajaran ini berdasarkan pada apa yang membuat siswa tertarik. Retman dalam Sudjana (2001) mengemukakan kegiatan belajar perlu mengutamakan pemecahan masalah karena dengan menghadapi masalah siswa akan didorong untuk menggunakan pikiran secara kritis dan bekerja secara intensif untuk memecahkan masalah yang dihadapi dalam kehidupan.

Selain strategi pembelajaran kooperatif tipe think pair share, guru dapat juga menerapkan strategi pembelajaran kooperatif tipe jigsaw. Pada strategi pembelajaran kooperatif tipe jigsaw, siswa diberi kesempatan untuk menemukan ide pokok, untuk saling berpikir kemudian dibahas bersama, siswa juga diberi kesempatan untuk saling mengajarkan kepada teman lain dalam kelompoknya dan saling mentransfer ilmunya. Strategi pembelajaran pembelajaran kooperatif tipe think pair share merupakan strategi pembelajaran pembelajaran kooperatif, dengan siswa belajar dalam kelompokkelompok kecil secara heterogen dan bekerjasama saling ketergantungan yang positif dan bertanggung jawab atas ketuntasan bagian materi pelajaran yang harus dipelajari dan menyampaikan materi tersebut kepada anggota kelompok yang lain.

\section{E. KETERBASAN PENELITIAN}

Sebagai suatu karya ilmiah, penelitian ini telah dilakukan sebaik mungkin sesuai dengan prosedur karya ilmiah. Keterbatasan dan kelemahan yang dapat diamati dan mungkin terjadi selama penelitian berlangsung di antaranya adalah:

1. Penelitian ini hanya dilakukan pada siswa kelas VI SD Muhammadiyah 12 Medan tahun pembelajaran 2014/2015, sehingga hasil penelitian hanya dapat digeneralisasikan terhadap populasi yang memiliki 
karakteristik sama dengan sampel penelitian di daerah lain.

2. Strategi pembelajaran kooperatif hanya dilakukan pada satu materi pelajaran saja yaitu pada materi menghitung luas dan volume. Dengan demikian untuk materi pelajaran lain, penggunaan strategi pembelajaran kooperatif tipe think pair share dan strategi pembelajaran kooperatif tipe jigsaw harus dikaji lebih mendalam lagi.

3. Terbatasnya waktu yang tersedia, sehingga hanya dilakukan 5 (lima) kali pertemuan. Seharusnya pelaksanaan strategi pembelajaran kooperatif membutuhkan waktu lebih panjang dan lebih sering dilakukan mengingat variabel terikatnya adalah kemampuan berpikir kritis dan hasil belajar matematika siswa.

4. Data hasil belajar matematika diperoleh dengan menggunakan tes pilihan berganda yang diberikan terhadap responden yang dipilih. Pengukuran dengan tes pilihan berganda mempunyai keterbatasan seperti: (a) persiapan untuk menyusun tes jauh lebih sulit, (b) soal-soalnya cenderung untuk mengungkapkan dan daya pengenalan kembali saja, (c) banyak kesempatan untuk main untung-untungan, dan (d) kerjasama antara siswa pada waktu pengerjaan soal tes lebih terbuka. Salah satu dari keempat keterbatasan tersebut perlu dipertanyakan, yakni tentang kerjasama antara siswa pada waktu pengerjaan soal matematika lebih terbuka. Dalam hal ini menyebabkan adanya kemungkinan bahwa siswa telah bekerjasama antara beberapa orang siswa dalam memberikan jawaban. Untuk mengatasi ini sudah diusahakan melakukan pengawasan ketika tes dilakukan dan juga menghimbau siswa untuk berlaku jujur dengan memberikan jawaban sesuai kemampuannya.

\section{F. PENUTUP}

\section{Simpulan}

a. Kemampuan berpikir kritis pada materi pokok menghitung luas dan volume siswa kelas strategi pembelajaran kooperatif tipe think pair share lebih tinggi daripada kelas strategi pembelajaran kooperatif tipe jigsaw dan pembelajaran konvensional siswa kelas VI SD Muhammadiyah 12 Medan. Rata-rata nilai kemampuan berpikir kritis siswa yang dibelajarkan dengan strategi pembelajaran kooperatif tipe think pair share sebesar 76,792, secara signifikan lebih tinggi dibandingkan kemampuan berpikir kritis siswa yang dibelajarkan dengan strategi pembelajaran kooperatif tipe jigsaw 74,320 dan yang dibelajarkan dengan strategi konvensional 66,069. Hasil ini menunjukkan untuk peningkatan kemampuan berpikir kritis pada pokok bahasan bangun ruang di kelas VI sebaiknya guru menggunakan strategi pembelajaran think pair share.

b. Hasil belajar matematika pada materi pokok menghitung luas dan volume siswa kelas strategi pembelajaran kooperatif tipe think pair share lebih tinggi daripada kelas strategi pembelajaran kooperatif tipe jigsaw dan pembelajaran konvensional siswa kelas VI SD Muhammadiyah 12 Medan. Rata-rata nilai hasil belajar siswa yang dibelajarkan dengan strategi pembelajaran kooperatif tipe think pair share sebesar 80,625, secara signifikan lebih tinggi dibandingkan hasil belajar yang dibelajarkan dengan strategi pembelajaran kooperatif tipe jigsaw 79,000 dan yang dibelajarkan dengan strategi konvensional 69,310 . Hasil ini menunjukkan untuk peningkatan hasil belajar Matematika pada pokok bahasan bangun ruang di kelas VI sebaiknya guru menggunakan strategi pembelajaran think pair share.

\section{Implikasi}

a. Dengan diterimanya hipotesis pertama yang diajukan, yakni terdapat pengaruh strategi pembelajaran kooperatif tipe think pair share, strategi pembelajaran kooperatif tipe jigsaw, dan pembelajaran konvensional terhadap kemampuan berpikir kritis siswa pada materi pokok menghitung luas dan volume di kelas VI SD Muhammadiyah 12 Medan. Untuk itu perlu dilakukan upaya dalam pengembangan pembelajaran di kelas menggunakan strategi pembelajaran kooperatif tipe think pair share. Dengan strategi pembelajaran kooperatif tipe think pair share, proses pembelajaran di kelas dapat berjalan baik, serta siswa dapat memaksimalkan kemampuan berpikir kritisnya. Hal ini harus terus dikembangkan mengingat kesimpulan penelitian bahwa kemampuan berpikir kritis siswa dapat ditingkatkan melalui strategi pembelajaran kooperatif tipe think pair share, dibanding strategi pembelajaran kooperatif tipe jigsaw, pembelajaran konvensional.

b. Dengan diterimanya hipotesis kedua yang diajukan, yakni terdapat pengaruh strategi pembelajaran kooperatif tipe think pair share, strategi pembelajaran kooperatif tipe jigsaw, dan pembelajaran konvensional terhadap hasil belajar siswa pada materi pokok menghitung luas dan volume di kelas VI SD Muhammadiyah 12 Medan. Untuk itu perlu dilakukan upaya dalam pengembangan pembelajaran di kelas menggunakan strategi pembelajaran kooperatif tipe think pair share. Dengan strategi pembelajaran kooperatif tipe think pair share, proses pembelajaran di kelas dapat berjalan baik, serta siswa dapat meningkatkan hasil belajarnya. Hal ini harus terus dikembangkan mengingat kesimpulan penelitian bahwa hasil belajar matematika siswa dapat ditingkatkan melalui strategi pembelajaran kooperatif tipe think pair share, dibanding strategi pembelajaran kooperatif tipe jigsaw, dan pembelajaran konvensional.

\section{Saran}

a. Untuk meningkatkan pembelajaran di kelas menggunakan strategi pembelajaran kooperatif dalam meningkatkan kemampuan berpikir kritis siswa, perlu dilakukan berbagai upaya di antaranya: melakukan pelatihan dan pembelajaran kepada guru tentang cara menggunakan strategi pembelajaran 
kooperatif khususnya tipe think pair share. Beberapa upaya yang dapat dilakukan guru di antaranya dengan membangun pemahaman yang baik tentang konsep-konsep matematika akan sangat bermanfaat bagi siswa, sehingga siswa terbiasa menggunakan pola pikir sistematis, rasional, cermat, jelas, dan akurat sesuai dengan ciri mata pelajaran matematika sesuai dengan benda-benda berbentuk bangun ruang di sekitarnya. Selain itu, guru juga dapat meningkatkan kemampuan berpikir kritis siswa dengan memberikan masalah, mengajukan pertanyaan, dan memfasilitasi penyelidikan dan dialog.

b. Untuk meningkatkan pembelajaran di kelas menggunakan strategi pembelajaran kooperatif dalam mendukung peningkatan hasil belajar siswa, perlu dilakukan berbagai upaya di antaranya: merangsang guru untuk bersedia menggunakan strategi pembelajaran kooperatif khususnya tipe think pair share. Dalam hal ini, disarankan guru untuk melakukan upaya tertentu seperti: membentuk kelompok belajar siswa, memberikan masalah pelajaran yang berhubungan dengan dunia siswa, mengorganisasi materi pembelajaran sesuai dengan masalah, memberikan siswa tanggung jawab untuk mengarahkan pembelajarannya sendiri, dan menuntut siswa untuk menampilkan apa yang telah mereka pelajari melalui hasil belajar. Dengan upaya ini diharapkan pengetahuan dan kemampuan siswa dalam pembelajaran Matematika dapat ditingkatkan dan tercermin pada hasil belajar siswa.

c. Perlu diadakan penelitian yang lebih lanjut tentang keterkaitan kemampuan berpikir kritis dan hasil belajar siswa ditinjau dari pelaksanaan strategi pembelajaran kooperatif tipe khususnya tipe think pair share, untuk memperbanyak khasanah pengetahuan tentang strategi pembelajaran kooperatif dan pengaruhnya terhadap kemampuan berpikir kritis dan pembelajaran Matematika.

\section{DAFTAR RUJUKAN}

Arends, Richard. 2008. Learning to Teach. New York: McGraw Hill Company

Arikunto, Suharsimi. 2009. Dasar-Dasar Evaluasi Pendidikan. Jakarta: Rineka Cipta

Ennis, R.H., Gardiner, W.L., Morrow, R., Paulus, D., dan Ringel, L. 1964. Cornell Critical Thinking Test Series. Illinois: Urbana-Champaign

Freeman, R.E. 2007. Strategic Management: A Stakeholder Approach. Boston: Pitman

Getter, K.L. dan Rowe, D.B. 2008. "Using Simple Cooperative Learning Techniques in a Plant Propagation Course". NACTA Journal. P: 39-43

Husnidar, dkk. 2014. "Penerapan Model Pembelajaran Berbasis Masalah Untuk Meningkatkan Kemampuan Berpikir Kritis dan Disposisi Matematis Siswa", Jurnal Didaktik Matematika, Vol. I, No. I, April 2014

Ibe, N. 2009. "Metacognitive Strategies on Classroom Participation and Student Achievement in Senior Secondary School Science Classrooms". Science
Education International. Vol. 20, No.1/2, December 2009, 25-3

Lie, Anita. 2008. Cooperative Learning. Jakarta: Grasindo Masek, A. dan Yamin, S. 2012. "The Impact of Instructional Methods on Critical Thinking: A Comparison of Problem-Based Learning and Conventional Approach in Engineering Education". International Scholarly Research Network, Volume 2012, pp. 1-6

Nurhadi, dan Senduk, A.G. 2003. Pembelajaran Kontekstual (Contextual Teaching and Learning/CTL) dan Penerapannya Dalam KBK. Malang: Universitas Negeri Malang

Palennari, Muhiddin. 2011. "Potensi Strategi Integrasi PBL dengan Pembelajaran Kooperatif Jigsaw Dalam Meningkatkan Pemahaman Konsep Mahasiswa". Jurnal Ilmiah Pendidikan Biologi, Biologi Edukasi Volume 3, Nomor 2, Desember 2011, hlm 26-33.

Rustaman, N. dkk. 2003. Strategi Belajar Mengajar Biologi. Bandung: Universitas Pendidikan Indonesia

Sanjaya, Wina. 2005. Strategi Pembelajaran Berorientasi Proses Pendidikan. Jakarta: Kencana Perdana Media Grup

Solso, Robert L. 2007. Psikologi Kognitif. Jakarta: Erlangga Sudjana, N. 2001. Penilaian Hasil dan Proses Hasil Belajar. Bandung: Remaja Rosdakarya

Sugianto, Dian Armanto, dan Mara Bangun Harahap. 2014.

"Perbedaan Penerapan Model Pembelajaran Kooperatif Tipe Jigsaw dan STAD Ditinjau Dari Kemampuan Penalaran dan Komunikasi Matematis Siswa SMA". Jurnal Didaktik Matematika Vol. 1, No. 1, April 2014

Sungur, S., Tekkaya, C. dan Geban, O. 2006. "Improving Achievement Through Problem Based Learning". Journal of Biology Education, 40(4):155-160

Syah, M. 2008. Psikologi Belajar. Jakarta: Raja Grafindo Persada 